\title{
Portal venous air in an old male
}

\section{Diyu Chen, Jian Wu}

Division of Hepatobiliary and Pancreatic Surgery, Department of Surgery, the First Affiliated Hospital, School of Medicine, Zhejiang University, Hangzhou, China

Correspondence to: Jian Wu. Division of Hepatobiliary and Pancreatic Surgery, Department of surgery, the First Affiliated Hospital, School of Medicine, Zhejiang University, No. 79 Qingchun Road, Hangzhou 310000, China. Email: drwujian@zju.edu.cn.

Submitted Feb 17, 2020. Accepted for publication May 13, 2020.

doi: $10.21037 / \mathrm{hbsn}-20-302$

View this article at: http://dx.doi.org/10.21037/hbsn-20-302

A 77-year-old man admitted to our hospital of esophageal carcinoma. The patient had a past medical history of hypertension, atherosclerosis, cerebral infarction and prostate carcinoma with bone metastasis. Besides, he had the habit of drinking and smoking. The patient presented with vomiting, abdominal pain and fever during the $28^{\text {th }}$ day of hospitalization. Physical examination revealed diffuse abdominal tenderness and severe sepsis. Laboratory findings revealed elevated neutrophile granulocyte, $\mathrm{C}$ reaction protein (CRP) and lactic acid level. CT scanning indicated that air was accumulated in the branches of portal vein (Figure 1), and ischemic changes in the ventricle and half oval center (Figure 2). Based on these finding, the diagnosis of intestinal necrosis was made. Then the patient was treated with meropenem and linezolid, but the abdominal pain and fever still exacerbated. The patient died of multiple organ failure 4 hours later.
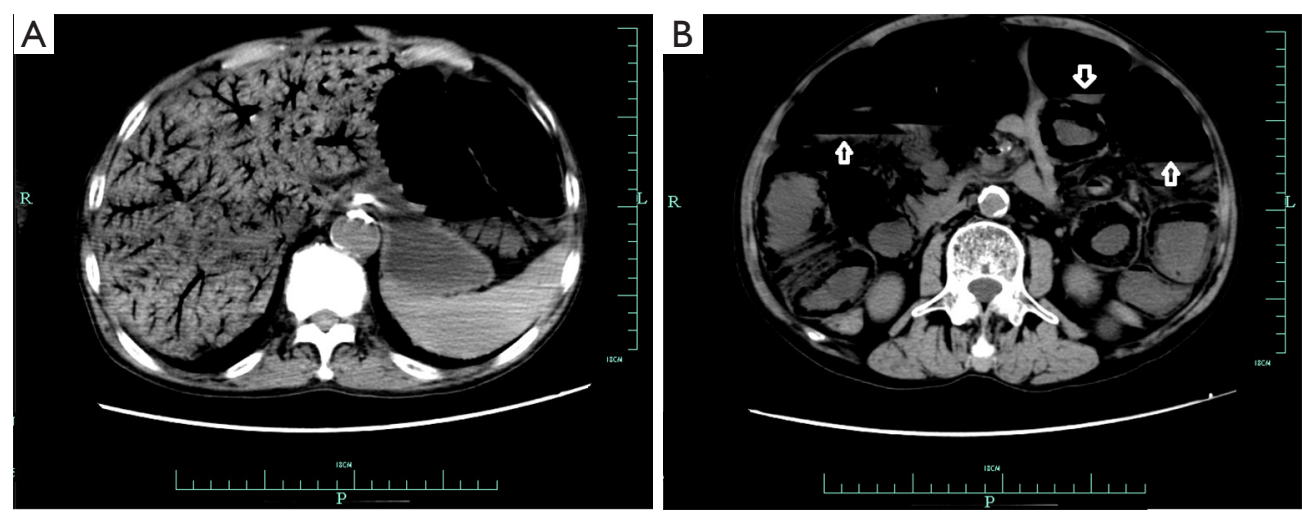

Figure 1 The computed tomography (CT) scanning presented the portal venous air in the patient. (A) CT showed air in the portal vein and its branches, extended pneumatosis intestinalis with portomesenteric gas in superior mesenteric vein. (B) Gas-fluid levels (arrows) were detected in the gastrointestinal tract. 


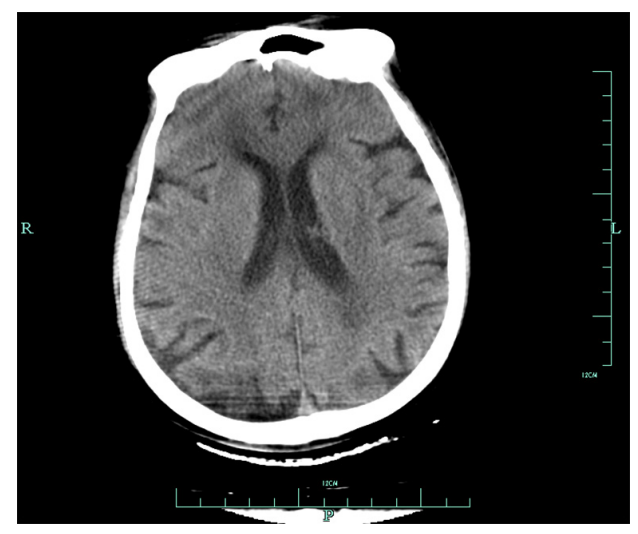

Figure 2 Skull CT examination showed ischemic changes in both sides of the ventricle and half oval center.

\section{Acknowledgments}

The authors thank Dr. Xiaofeng Xu for providing help to this research.

Funding: None.

\section{Footnote}

Provenance and Peer Review: This article was a standard submission to the journal Hepatobiliary Surgery and Nutrition. The article did not undergo external peer review.

Conflicts of Interest: Both authors have completed the ICMJE uniform disclosure form (available at https://hbsn. amegroups.com/article/view/10.21037/hbsn-20-302/coif). The authors have no conflicts of interest to declare.

Ethical Statement: The authors are accountable for all aspects of the work in ensuring that questions related to the accuracy or integrity of any part of the work are appropriately investigated and resolved.

Open Access Statement: This is an Open Access article distributed in accordance with the Creative Commons Attribution-NonCommercial-NoDerivs 4.0 International License (CC BY-NC-ND 4.0), which permits the noncommercial replication and distribution of the article with the strict proviso that no changes or edits are made and the original work is properly cited (including links to both the formal publication through the relevant DOI and the license). See: https://creativecommons.org/licenses/by-nc-nd/4.0/.

Cite this article as: Chen $\mathrm{D}, \mathrm{Wu} \mathrm{J}$. Portal venous air in an old male. HepatoBiliary Surg Nutr 2021;10(1):149-150. doi: 10.21037/ hbsn-20-302 